\title{
A remarkable activity of steroid biosynthesis in captopril preserved Leydig cells of mice implicated leukotriene B4 and gonadotropin releasing hormones in vitro
}

\author{
Mohanad A. Al-Bayati \\ Pharmacology and Toxicology, Department of Physiology and Pharmacology, College of Veterinary Medicine, University of Baghdad, \\ Baghdad, Iraq
}

Email address:

aumnmumu@yahoo.com

To cite this article:

Mohanad A. Al-Bayati. A remarkable Activity of Steroid Biosynthesis in Captopril Preserved Leydig Cells of Mice Implicated Leukotriene B4 and Gonadotropin Releasing Hormones in vitro. American Journal of BioScience. Vol. 2, No. 6, 2014, pp. 203-210.

doi: 10.11648/j.ajbio.20140206.13

\begin{abstract}
In this study, investigated whether captopril inhibited steroidogenesis and components of the Leukotriene B4 pathways are involved in GnRH agonist ( $\mathrm{GnRH})$-induced testis steroidogenesis in mice Leydig cells. Primary cultures of mice Leydig cells were established. Purified Leydig cells from adult albino mice were incubated with gradual various concentrations of GnRH with and without Captopril, Luteinizing hormone (LH); LTB4, steroidogenic (testosterone) activity and LTB4 concentration were measured after various time intervals and Leydig cell viability. The maneuvers of Leydig cells treated media was covered the singular and dual actions of antisteroidogenic of captopril and the reversible activity by GnRH-LTB4 as well as contribution of LTB4 in Leydig cells testosterone production endpoint. The different treatment media are Medium alone; Medium plus captopril $60 \mu \mathrm{M}, 65 \mu \mathrm{M}, 70 \mu \mathrm{M}, 75 \mu \mathrm{M}$ and $80 \mu \mathrm{M} 100 \mu \mathrm{M}$; Medium plus 2.5mU/ml leukotriene B4; Medium plus $0.1 \mathrm{mM}$ LH; Medium plus $0.1 \mu \mathrm{M}$ GnRH; Medium plus $65 \mu \mathrm{M}$ captopril plus $2.5 \mathrm{mU} / \mathrm{ml}$ leukotriene B4;Medium plus $65 \mu \mathrm{M}$ captopril plus $0.1 \mathrm{mM}$ LH; Medium plus $65 \mu \mathrm{M}$ captopril plus $0.1 \mathrm{mM} \mathrm{GnRH}$; Medium plus $0.1 \mathrm{mM}$ GnRH plus $2.5 \mathrm{mU} / \mathrm{ml}$ leukotriene B4 and Medium plus $65 \mu \mathrm{M}$ captopril plus $0.1 \mathrm{mM} \mathrm{GnRH}$ plus $2.5 \mathrm{mU} / \mathrm{ml}$ leukotriene B4. Basal testosterone levels were maximal at $0.1 \mu \mathrm{M}$ GnRH concentration and superior testosterone yield in Leydig cells incubated 0.1 $\mu \mathrm{M}$ GnRH media than without GnRH media, and the activity profile LTB4 flow up. That comparable result led to highly correlated approved the contribution of LTB4 in GnRH stimulated Leydig cell steroidogenic end point. Furthermore captopril had an abolishment effect partially of testosterone yield and recovered and improved by GnRH and LTB4. The Leydig cells viability results suggest that the major effect of GnRH is probably beyond the LTB4. The entire key; GnRH induced testosterone production and upregulated LTB4 Levels at both the captopril inhibitory LTB4-testesteron Leydig cells culture media and captopril abolished LTB4 levels; it also activated endogenous LTB4, but not LH motivated testosterone pathway. Our data show that GnRH positively regulates steroidogenesis via LTB4 signaling in mice Leydig cells. LTB4 activation by GnRH may be responsible for the induction of $\mathrm{Ca}^{++}$signaling indirect. Possibility improve the captopril steroidogenic disruption in Leydig cells via LTB4 and/or GnRH induction of endogenous LTB4, likewise the positive maintenance of Leydig cells viability matched induce testosterone synthesis. The LTB4 production, which may ultimately modulate steroidogenesis in mice Leydig cells, and promise new antidotal and preventative of captopril adverse effects.
\end{abstract}

Keywords: Captopril, Leukotriene B4, GnRH, Testosterone, Leydig Cell, LTB4, Steroidogenic

\section{Introduction}

The use of chemotherapeutics drugs is known to cause multi adverse effects in multi organ systems (1). Permanent malfunction of gonads and infertility have been reported as unwanted effects of chemotherapeutic drugs in males. One of common pharmaceutics is captopril, act as an inhibitory action of the renin-angiotensin system joined as complex regulatory system generating octapeptide angiotensin II, including decreases in glomerular blood flow and in plasma Sodium concentration also Captopril demonstrates irreversible noncompetitive and competitive inhibitor of tyrosinase monophenolase and diphenolase activities, 
respectively. Long term use of captopril for chronic hypertensive cases and other medications were reported in several medicinal planning (26). That must redirection of idea reboot disruption of hormonal synthesis due to many factors accompanying with mode of captopril action interference with eicosanoid and unsaturated free fatty acid derivative. Steroidogenesis is translated their activity by harmony of homeostasis.

Several notions in the available literatures considering male antifertility as an incentive of captopril medication properties and it was not well known on which location it will target of the testicular structures and broadly aimed to steroid biosynthesis.

It has been generally acknowledged that Leydig cells play a key role in synthesizing testosterone and regulating the spermatogenesis. The final population of Leydig cells in the adult testis is established depending on the proliferation and differentiation of Leydig cells at prepuberty period and develops to the adult population of Leydig cells [1, 2]. The adult Leydig cells develop from stem Leydig cells through several steps of differentiation and proliferation which occur during prepuberty stage (3).

Furthermore, it is known that short-term in vitro treatment of $\mathrm{GnRH}$ stimulates testosterone production by adult rat Leydig cells (27), whereas, long-term incubation decreases the response to LH (28). In addition, GnRH or its agonist induced paradoxical effects on testosterone secretion in adult hypophysectomized rats (29) by inhibiting basal and LHdependent steroidogenesis in rat fetuses in vivo. Some studies from various species reveal that $\mathrm{GnRH}$ agonists or GnRHlike materials have positive effects on testosterone production (30). These observations suggest that GnRH has direct effects on Leydig cells, and these effects might be species-specific.

The literature reveled to the LTB4 had influence under LH effect and that LTB4 is produced in Leydig cells and can be stimulated by high calcium levels, but that it is probably not required for the control of steroidogenesis (15).

Previous work from different laboratories had shown that inhibitors of the LTB4 do not contribution to Leydig cell steroid biosynthesis pathway of LTB4 inhibitor, without taking into consideration to GnRH effect which stimulates LTs and its involvement with adverse effect of a potent inhibition of LTB4. This effect leads into direct or indirect disturbances of steroidogenesis in Leydig cells.

As part of an investigation into the role of leukotrienes under captopril - GnRH mediated maneuver in steroidogenesis. The present study attempts to determine the involvement of captopril as a GnRH could activate murine Leydig cell steroidogenesis.

\section{Material and Methods}

\subsection{Animal and Testis Preparation}

Mature mice (albino BALB C) weighing 25-27 g, agematched mice between 6 and 8 weeks of age were used.
These experimental animals were obtained from the College of Veterinary Medicine-University of Baghdad colony and housed in the animal facilities of the physiology and pharmacology department, animal house care department. Animals had access to standard diet (pellet "Al-Mored factory for concentrate" Iraq local market) and tap water $\mathrm{ad}$ libitum with $25 \pm 2 \mathrm{C}^{\circ}$ and dark/light cycle of 10:14 for two week before and during experiment so what is the total duration, 2 weeks or one, not clear. Animal care and management were carried out with ACAC protocol Western University of Health Science protocol and college of veterinary medicine committee on animals.

The testes of the mice were incised after (euthanasia using pentobarbital $10 \mathrm{mg} / \mathrm{kg} . \mathrm{BW}$ ) and collected in a prechilled $1: 1$ mixture of Ham's F12 medium and DMEM (Mediatech, Manassas, VA, USA) at $34^{\circ} \mathrm{C}$ for $20 \mathrm{~min}$, and placed on ice with the procedure performed as previously described (Zhang and Cui, 2009).

Isolation and Purification of Leydig Cells a new term why did you use it?

Leydig cells were isolated from the mice as previously described (2) using the following steps:

Step 1, dissociation and digestion: After removal of the testes' tunica albuginea, seminiferous tubules were dissociated in the medium (dissociation buffer) and subjected to enzymatic digestion in the shaking water bath, using $5 \mathrm{mg}$ collagenase (type IV, $213 \mathrm{U} / \mathrm{mg}$; Worthington Biochemical Corp., Freehold, NJ, USA) in a buffered media (M199 medium with $2.2 \mathrm{~g} / \mathrm{L}$ of Hepes, $0.1 \%$ bovine serum albumin, $25 \mathrm{mg} / \mathrm{L}$ of trypsin inhibitor, and $0.7 \mathrm{~g} / \mathrm{L}$ of sodium bicarbonate) $\mathrm{pH} 7.4$ at 80 oscillations (osc)/min, (3 and 4). Following this digestion procedure, the collagenase solution was diluted four times with a culture medium, and then filtered through a nylon mesh $(100 \mu \mathrm{m})$ to separate tissue fragments. The cells were then collected via centrifugation (1,500 rpm for $10 \mathrm{~min}$ ) and re-suspended in $2 \mathrm{~mL}$ of the culture medium mentioned above.

Step 2, Leydig cells purification: The Leydig cells were purified discontinuously with a four-layer Percoll (SigmaAldrich, St. Louis, MO, USA)(95\% 1× Hank's balanced salt solution, HBSS; Invitrogen, Carlsbad, CA, USA) density gradient $(21 \%, 26 \%, 37 \%$, and $60 \%)$ in a conical tubes. The gradient was centrifuged at $3,000 \mathrm{r} / \mathrm{min}$ for $30 \mathrm{~min}$ at $4{ }^{\circ} \mathrm{C}$; the interface between $37 \%$ and $60 \%$ was collected and washed with the medium to remove the Percoll. The cells isolated from the adult Leydig cells according to (O'Shaughnessy et al. (2009).

\subsection{Purity and Viability}

The purity of the Leydig cells determined by histochemical staining for $3 \beta$-HSD using $1 \mathrm{mg} / \mathrm{mL}$ etiocholanolone as the enzyme substrate was observed to be $85 \%$. Some of the purified Leydig cells were used for detecting the viability and purity, and others for Leydig cell culture (6) was greater than $95 \%$ in all experiments. The viability of the cells, as assessed by trypan blue exclusion, was greater than $90 \%$ Guoxin et al. (2010). 


\subsection{Cell Culture and Treatment}

The purified Leydig cells were placed in 24 well plates $(1$ $\times 105$ cells per well) with Ham's F12/DMEM culture medium supplemented with $10 \% \mathrm{v} / \mathrm{v}$ charcoal-stripped fetal bovine serum and $1 \%$ penicillin-streptomycin. Culture was done at $34^{\circ} \mathrm{C}$ in a humidified atmosphere of $5 \%$ carbon dioxide and $95 \%$ air. After remaining for $24 \mathrm{~h}$ in the culture, then the cells cultures were washed four time by a serum-free medium, and treated with different leukotriene B4 from (Cayman Co) concentrations ( $1 \mu \mathrm{M}, 2 \mu \mathrm{M}, 4 \mu \mathrm{M}, 6 \mu \mathrm{M}$ and $8 \mu \mathrm{M})$ and captopril $(60 \mu \mathrm{M}, 65 \mu \mathrm{M}, 70 \mu \mathrm{M}, 75 \mu \mathrm{M}$ and $8 \mu \mathrm{M})$ IC50 $63 \mu \mathrm{M}$ for $24 \mathrm{~h}$. After the incubation, the Leydig cells were collected from the 24-well plates. GnRH (RIA. Laboratories, Al-Hartheia, Baghdad-Iraq).

\subsection{Treatment Protocol}

To explore testicular steroidogenesis production, the Leydig cells isolate transferred to the plate's well, where they were distributed over incubation wells testes how is this possible, 2 testes?/well) each containing $2 \mathrm{ml}$ of incubation medium (10). Each incubation set of wells was divided into six experimental groups (each consisting of 4 wells):

1) Medium alone;

2) Medium plus captopril $60 \mu \mathrm{M}, 65 \mu \mathrm{M}, 70 \mu \mathrm{M}, 75 \mu \mathrm{M}$ and $80 \mu \mathrm{M} 100 \mu \mathrm{M}$;

3) Medium plus $2.5 \mathrm{mU} / \mathrm{ml}$ leukotriene $\mathrm{B} 4$;

4) Medium plus $0.1 \mathrm{mM} \mathrm{LH}$;

5) Medium plus $0.1 \mu \mathrm{M} \mathrm{GnRH}$;

6) Medium plus $65 \mu \mathrm{M}$ captopril plus $2.5 \mathrm{mU} / \mathrm{ml}$ leukotriene B4;

7) Medium plus $65 \mu \mathrm{M}$ captopril plus $0.1 \mathrm{mM} \mathrm{LH}$;

8) Medium plus $65 \mu \mathrm{M}$ captopril plus $0.1 \mathrm{mM} \mathrm{GnRH}$;

9) Medium plus $0.1 \mathrm{mM}$ GnRH plus $2.5 \mathrm{mU} / \mathrm{ml}$ leukotriene B4;

10) Medium plus $65 \mu \mathrm{M}$ captopril plus $0.1 \mathrm{mM} \mathrm{GnRH}$ plus $2.5 \mathrm{mU} / \mathrm{ml}$ leukotriene B4

Inductions of steroidogenesis, all media of incubation set were incubated for $18 \mathrm{~h}$ at $100 \mathrm{ng} / \mathrm{ml} \mathrm{LH}$ except media 4 and 7.

\subsection{MTT Cell Viability Assay}

After the cells were preserved with variable dosages of captopril, leukotriene B4, LH and GnRH for 2, 6, 12, 18, 24 hours, the viability of cells were assayed as follow (9)

1) The culture medium was filtered out and the cells were harvested,

2) Re-suspended in $200 \mu \mathrm{L}$ 3-(4, 5-dimethylthiazol-2yl)-2, 5-diphenyltetrazolium bromide (MTT) stock solution; $5 \mathrm{mg} / \mathrm{ml}$ methyl thiazolyldiphenyl-tetrazolium bromide in phosphate-buffered saline, then incubated for 2 hours at $37 \mathrm{C}^{\circ}$.

3) The converted dye was solubilized with $3 \mathrm{ml}$ acidic isopropanol $(0.04 \mathrm{M} \mathrm{HCl}$ in absolute isopropanol).

4) The absorbance of which was measured at a wavelength of $570 \mathrm{~nm}$ with a background subtraction at $650 \mathrm{~nm}(8)$.
Testosterone Radioimmunoassay and leukotriene B4 assay

To assess the time and dose responses of primary and Leydig cells to captopril, GnRH, leukotriene B4, and LH, with combination groups, the purified incubated Leydig cells at a concentration of approx. 200000 cells $/ 0.5 \mathrm{ml}$ were incubated in 96-well Falcon culture plates with LH (100 $\mathrm{ng} / \mathrm{ml}$ ) and then centrifuged at $100 \mathrm{~g}$ for $5 \mathrm{~min}$. At the end of incubation, the supernatant media were separated and kept frozen at $-20^{\circ} \mathrm{C}$ until assay for LTB4 (Salmon et al., 1982) (36).

Testosterone assay (primary cell cultures) by radioimmunoassay (RIA)

The RIA procedure used in this experiment was after Verjans et al. (35)

\section{Determination of LTB4 by ELISA}

The LTB4 ELISA kit (abcam) is a competitive immunoassay for the quantitative determination of LTB4 in biological fluids. The Assay Designs Leukotriene B4 Enzyme Immunoassay, "competitive manner" briefly, a polyclonal antibody were used to LTB4 to bind, the LTB4 in the sample which has LTB4 covalently attached to it. After incubations at room temperature the excess reagents are washed away and substrate is added. After 2 hours incubation, the enzyme reaction is stopped and the yellow color created is read at $405 \mathrm{~nm}$. The intensity of the bound yellow color is inversely proportional to the concentration of LTB4 in either standards or samples. The measured optical density is used to determine the concentration of $\mathrm{LTB}_{4}$. The recovery $\% 97.3$ for assay.

\subsection{Statistical Analysis}

Treatments were achieved in duplicates unless otherwise stated. Each groups consisted of at least eight replicates. The data are reported as the mean \pm SEM. Statistical analysis was performed using F-test "one way analysis ANOVA", with the latter followed by the Student-Newman-Keuls test of multiple data sets if $\mathrm{P}<0.05$ by ANOVA, using the Prism 4.02 software package from GraphPad, Inc.

\section{Results}

Purified cultures of mice Leydig cells were preserved with $\mathrm{LH}$ at $0.1 \mathrm{mM}$ concentrations or for different durations $(2,6$, 12,18 and $24 \mathrm{~h}$ ), and the viability of Leydig cells was examined by MTT assay. During a $24 \mathrm{~h}$ incubation, LH treated media a significantly $(P<0.05)$ increase Leydig cells viability over the baseline gradually increase $(P<0.05)$ at maximum $18 \mathrm{~h}$ (Figure 1).

All captopril treated media preserved Leydig cells also caused a significant decrease in viability $(P<0.05)$ at media (M) media-captopril (MC), media-captopril Luteinizing hormone (MCLH), media-capotopril-GnRH (MCG) as compared with other treated group but showed the GnRH and LTB4 recovered the viability of Leydig cells in captopril treated media an effect at $18 \mathrm{~h}$ (Figure 2). Optimal viability of Leydig cells were obtained when the cells were treated with GnRH and GnRH-LTB4. 


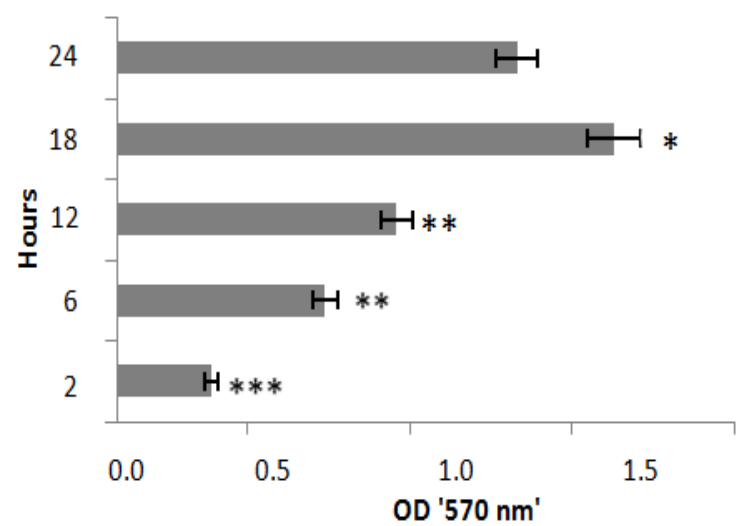

2.0

Figure 1. LH at doses of $0.1 \mathrm{mM}$ on the viability of Leydig cells from mice on control media. The viability of Leydig cells incubated using 2, 6, 12, 18 and $24 \mathrm{~h}$ and was assessed using MTT assays. The data were presented as means \pm S.E.M and $N$ eight replicates set. A single asterisk * indicates statistical significance $(P<0.05)$ relative to the time set.

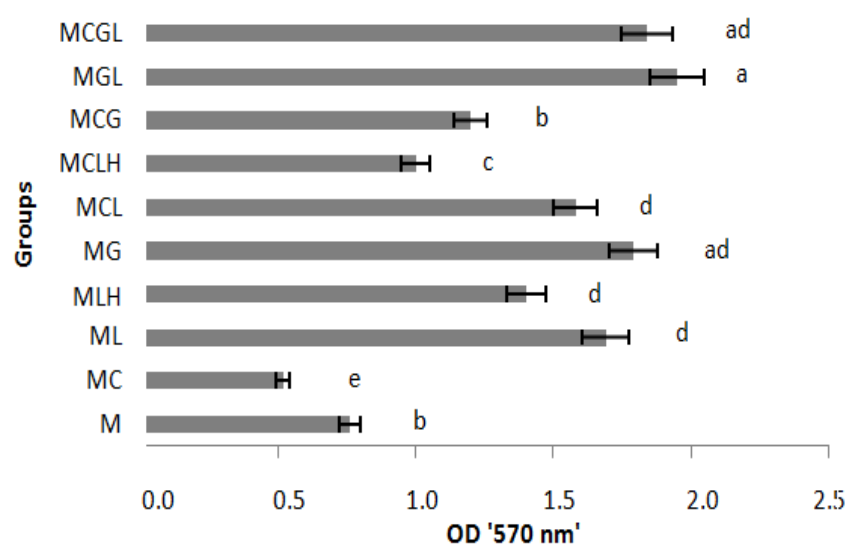

Figure 2. Captopril, GnRH, leukotriene B4, and LH at doses of $70 \mu \mathrm{M}, 0.1$ $\mu M, 2.5 \mathrm{mU} / \mathrm{ml}$, and $0.1 \mathrm{mM}$ respectively on the viability of Leydig cells from mice. The viability of Leydig cells incubated with different doses for $18 \mathrm{~h}$ was assessed using MTT assays. The data were presented as means \pm SEM. A letter indicates statistical significance $(P<0.05)$ relative to the untreated control. Control Medium alone (M); Medium plus captopril (MC); Medium plus leukotrieneB4 (ML); Medium plus LH; Medium plus GnRH MG; Medium plus captopril plus leukotriene B4 (MCL); Medium plus captopril plus LH (MCLH); Medium plus captopril plus GnRH (MCG); Medium plus GnRH plus leukotriene B4 (MGL); Medium plus captopril plus GnRH plus leukotriene B4 (MCGL)

The level of LTB4 and testosterone gradually increased to base line in same style with GnRH different dose and set as maximum at $0.1 \mu \mathrm{M}$ of GnRH (Figure 3 of LTB4 and 6 of testosterone).

When cells were treated with GnRH in a manner similar to the line guide in both Figures (4 and 7) for LTB4 and testosterone respectively and, both appearance increased $(p<0.05)$ at their levels after $6 \mathrm{~h}$ diverge increasing the media - GnRH more than without GnRH.

The mean testosterone levels increased steadily $6-24 \mathrm{~h}$ post-treatment and gradually returned to baseline after $48 \mathrm{~h}$ (Figure 1b). While the increases compared to the baseline levels were statistically significant at 6 or $24 \mathrm{~h}(\mathrm{P}<0.05)$, they were higher of both testosterone and LTB4.
To investigate whether captopril inhibit the LTB4 in the mice Leydig cells, I measured the level of LTB4 specifically recognize the role of captopril in LTB4 level ranks concentrations which where were exhibited lowering in the $\mathrm{M}, \mathrm{MC}$ and MCLH where medias MGLH, MG and MCG was recover the LTB4 levels superior than control media and captopril preserved medias (Figure 5).

Also examined the effects of captopril on GnRH-LTB4 induced steroidogenesis in mice Leydig cells. As shown in Figure 8 , treatment Media $\mathrm{M}$ and $\mathrm{MC}$ were showed significant $(\mathrm{p}<0.05)$ decrease basal testosterone levels as compared with media contains LTB4, GnRH and LH for $18 \mathrm{~h}$ incubation with notable that recover of testosterone levels in captopril loaded media with LTB4 and GnRH and LH or couple LTB4 and GnRH preserved Leydig cell media.

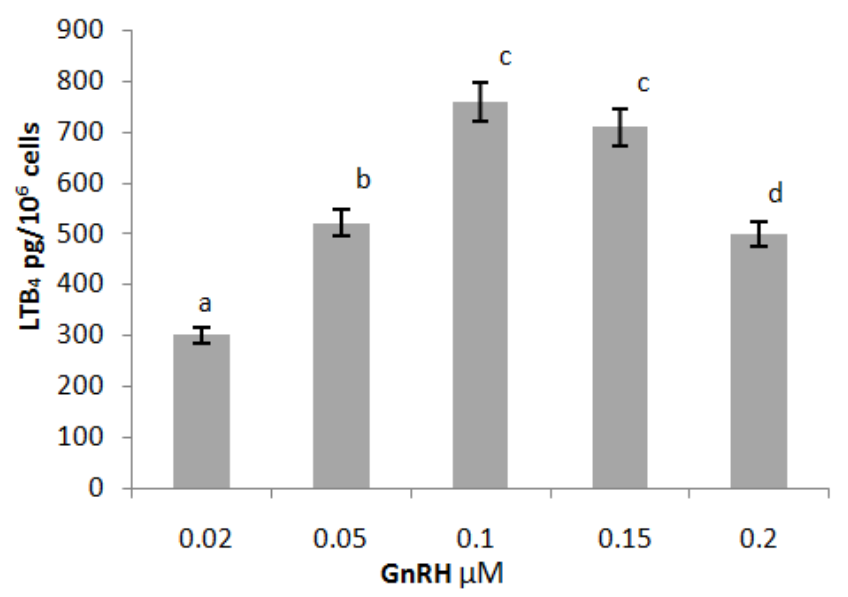

Figure 3. Dose effects of gonadotrophin-releasing hormone (GnRH) on leukotriene $B_{4}$ production in mice Leydig cells, Cells were dosed with various concentrations of $\operatorname{GnRH}(0.02,0.05,0.1,0.15$ and $0.2 \mu \mathrm{M})$ for $24 \mathrm{~h}$. Media were collected and assayed for leukotriene $B_{4}$ production by ELISA. Each data represents the mean \pm S.E.M of 9 replicates achieved in duplicate treatment. Different Litters denoted $P<0.05$, compared with the control.

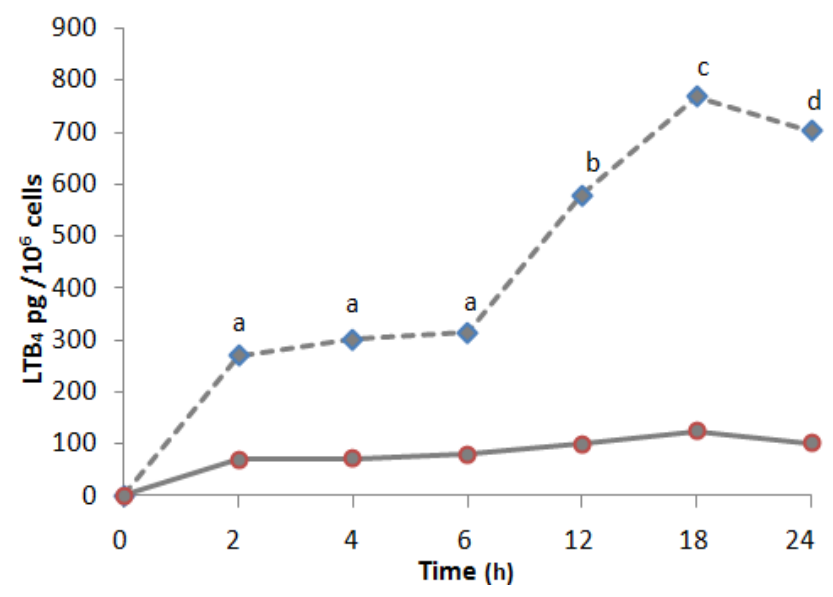

Figure 4. Temporal effects of gonadotrophin-releasing hormone (GnRH) on leukotriene $B_{4}$ production in mice Leydig cells, Cells were dosed with of GnRH $0.1 \mu \mathrm{M}$ (----) and control media (-) for various times. Leydig cells media were collected and assayed for leukotriene $B_{4}$ production by ELISA. Each data presents the mean \pm S.E.M of leukotriene $B_{4}$ production of 9 replicate performed in duplicate. Different Litters denoted $P<0.05$, compared with the control. 


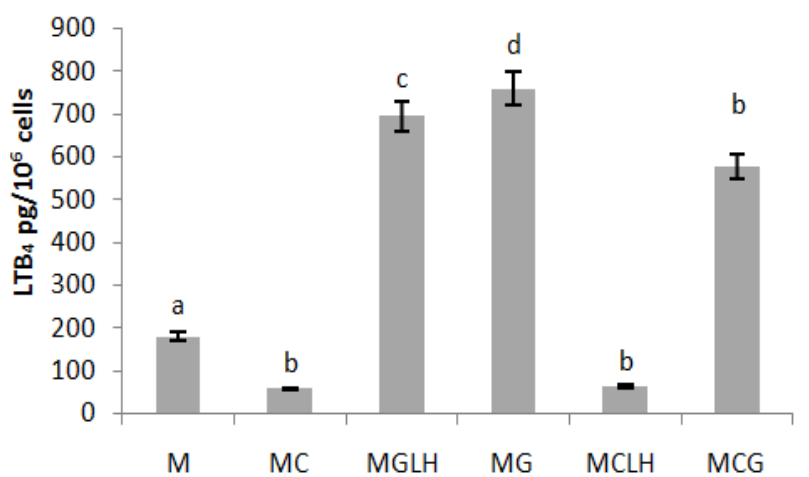

Figure 5. Effects of Captopril, GnRH, and LH at doses of $70 \mu M, 0.1 \mu M$, and $0.1 \mathrm{mM}$ on LTB4 production in mice Leydig cells, Control Medium alone (M); Medium plus captopril (MC); Medium plus LH; Medium plus GnRH MG; Medium plus captopril plus LH (MCLH); Medium plus captopril plus GnRH (MCG);

All data are means \pm S.E.M. $(\mathrm{n}=10)$ Different Litters denoted $\mathrm{P}<0.05$ versus media (control).

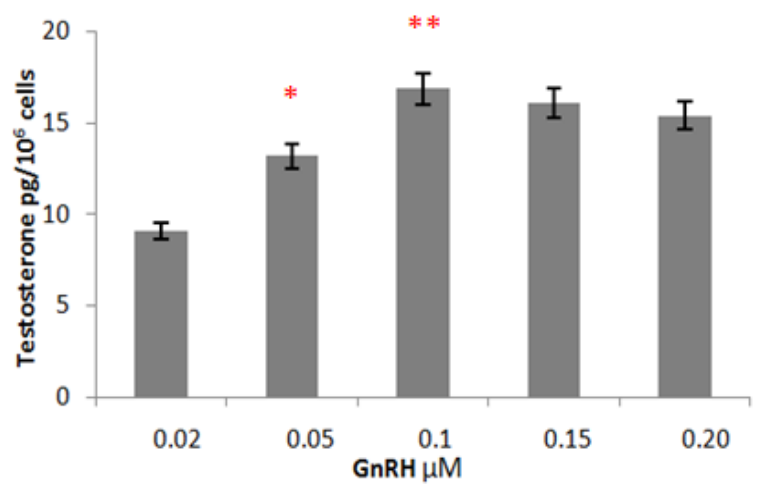

Figure 6. Dose effects of gonadotropin-releasing hormone (GnRH) on testosterone yield in mice Leydig cells, Cells were dosed with various concentrations of GnRH $(0.02,0.05,0.1,0.15$ and $0.2 \mu \mathrm{M})$ for $24 \mathrm{~h}$. Media were collected and evaluated for testosterone yield by RIA. The data denotes the mean \pm S.E.M of 9 replicates completed in duplicate treatment. Different Litters denoted $P<0.05$, compared with the control.

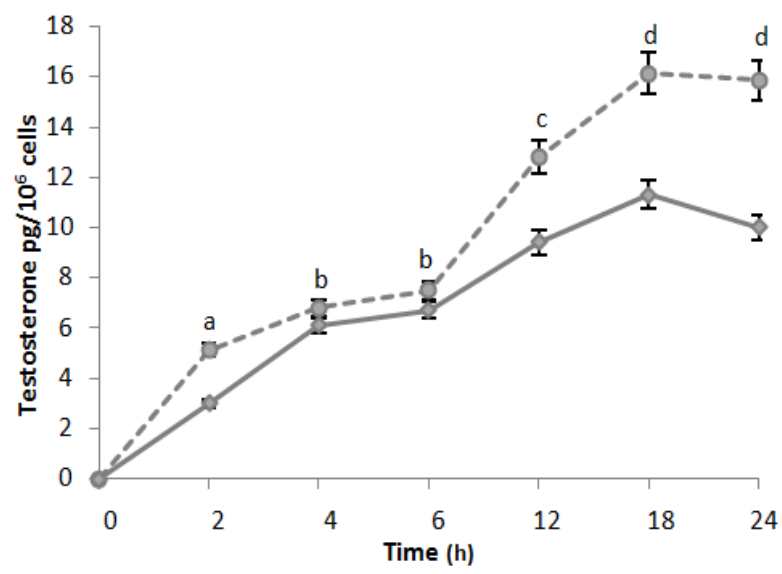

Figure 7. Time-based effects of gonadotrophin-releasing hormone (GnRH) on testosterone production in mice Leydig cells, Cells were dosed with of GnRH $0.1 \mu M$ (----) and control media () for various times. Leydig cells media were collected and assayed for testosterone production by RIA. Each data presents the mean \pm S.E.M of testosterone production of 9 replicate performed in duplicate. Different Litters denoted $P<0.05$, compared with the control.

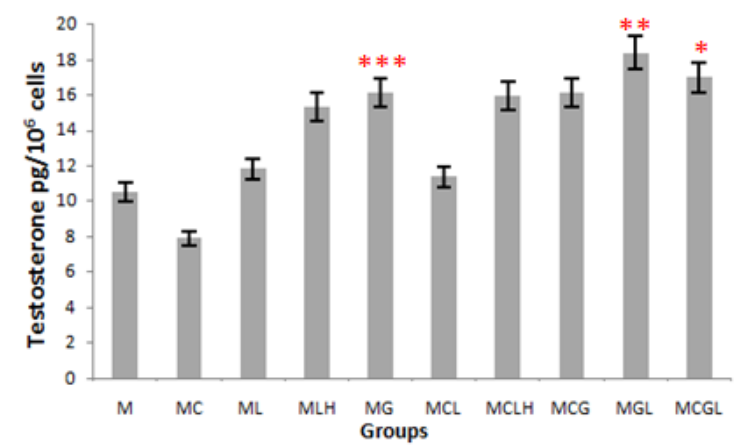

Figure 8. Effects of Captopril, GnRH, leukotriene B4, and LH at doses of $70 \mu \mathrm{M}, 0.1 \mu \mathrm{M}, 2.5 \mathrm{mU} / \mathrm{ml}$, and $0.1 \mathrm{mM}$ on testosterone production in mice Leydig cells, Control Medium alone (M); Medium plus captopril (MC); Medium plus leukotrieneB4 (ML); Medium plus LH; Medium plus GnRH MG; Medium plus captopril plus leukotriene B4 (MCL); Medium plus captopril plus LH (MCLH); Medium plus captopril plus GnRH (MCG); Medium plus GnRH plus leukotriene B4 (MGL); Medium plus captopril plus GnRH plus leukotriene B4 (MCGL), All data are means \pm S.E.M. $(n=10)$ Different stars denoted $P<0.05$ versus media (control).

\section{Discussion}

Captopril (crystalline powder; CAS 62571-86-2) is a reversible and competitive inhibitor of LTB4 and LTA4 synthesis in neutrophils in vitro and in vivo (10 and 24). Captopril has been shown to be an angiotensin converting enzyme-1 $\left(\mathrm{ACE}_{1}\right)$, but not $\mathrm{ACE}_{2}$. Captopril has also been shown to inhibit the formation of angiotensin II, a bioactive peptide that stimulates angiogenesis and increases microvessel density (17).

The steroidogenesis in testes is under physiological control of many hormones and extra-intra cellular factors. An adding of captopril is critical restricted the steroidogenic cells fade production in the testes for the formation of the steroid hormones. Captopril is directly exhausted biosynthesis of testosterone (18). Any alteration in these activities of mediators reflects on the androgen production. Reduced activities of these steroidogenic mediators in Leydig cells isolate and culture indicate reduced steroidogenesis (19 and 20).

The study designed to explore a short come of captopril on steroidogenic yield linked LTB4 bioavailability through an Idea of GnRH positively regulates steroidogenesis via LTB4 signaling in mice Leydig cells. Therefore, purified Leydig cells from normal mice testis showed excellent morphological preservation, the 10 X 124 Leydig cells recovered from 10 testes were isolated in a fraction comprised of $96 \%$ Leydig cells. Furthermore, the viability incubated Leydig cells harmonized with time, and set at 18 hours incubation time is maximal MTT viability of Leydig cells. These incubated Leydig cells exhibited a maximal viability response in both GnRH - LTB4 and CaptoprilGnRH-LTB4 treated media. Then less medium - LH preserved viable Leydig cells by our method under incubated for 18 hour in vitro (Bordy et al., 1984). While earlier studies had shown that LH is required for adult Leydig cell proliferation and activity, results from the current study show that adult Leydig cells differentiation will take place in animals deficient in LH (16). In other finding the LH has a 
stimulant of eicosanoids - LTB4 derived compound (31) and our results present GnRH stimulated endogenous LTB4 (Figure 3) that give an impression that LTB4 had contribution of Leydig cells proliferations. On the otherwise the GnRH induces steroidogenesis and LTB4 levels in coincided time of maximum response of Leydig cells synthesis profiles "18 hours" (figures 4 and 7) these follows the MTT test of Leydig cell viability figure (1).

Several opinions and reports had shown no role of LTB4 on the Leydig cells endocrine function (15). At this vision the study protocol demonstrated include the ability of contribution of LTB4 maintain the cellular viability via GnRH stimulation. And under stimulation of the endogenous LTB4 "medium containing GnRH "and in all medium containing LTB4 in the MMT viability test showed increased as comparing with documented captopril inhibit concentration of endogenous LTB4 figure (3). Furthermore, the recovery of Leydig cells viability linked to remodeling the cells concentration in treated medium reversed captopril inhibitory outcome through LTB4 figure (2). That reflected these evidences to steroidogenic concentration yield "testosterone" (figure 8).

The reports presented the captopril is a more potent inhibitor of LTB4 synthesis in cells, captopril had been shown to exhibit LTB4 inhibitory biosynthesis (24), and they are not able to satisfy the requirement of a small organic compound which is capable of cellular penetration. It would therefore be very advantageous to be able to provide low molecular weight inhibitors of LTB4 biosynthesis (5) which preferably exhibit activity in vivo at desirably low concentrations (11 and 10)

Furthermore the LTB4 - induced phosphorylation and reorganization through ERK activation in cells (32), the captopril inhibits LTB4 collapse the phosphorylation coupling cascades with sequel of upset of viability and steroidogenic yield.

In the present study concluded results indicated to; GnRH significantly activated the increase of LTB4 to stimulate Leydig cell testosterone production figure (5). These finding agree to direct contribution of GnRH activated LTB4 in Leydig cell steroidogenesis but no mediated the LH steroidogenesis (15) also recovered the LTB4 and steroidogenesis in preserved Leydig cells medium captoprilGnRH LTB4 (figure 2, 5 and 8).

In otherwise, cycloxygenated and lipoxygenated compounds play a diverse modulatory role on testicular steroidogenesis (31). And exogenous arachidonic acid stimulates testosterone secretion Whereas, Wang et al. (1983) other pathway that approved these results differ from previous reports proclaiming no direct effect of GnRH-LH on Leydig cell steroidogenesis [10]. In addition, GnRH exerted their effect by LTB4 receptors show different binding profiles to various eicosanoids and BLT antagonists. 12(S)hydroxyeicosatetraenoic acid and 15(S)hydroxyeicosatetraenoic acid binds to and activates BLT (19). These eicosanoids also induce calcium mobilization and chemotaxis through BLT2 (12).
Arguello et al. (2006) (33) the positive correlation in biosynthesis between LT44 and LTB4 that reflect on the captopril inhibitory of LTA4 led to inhibit LTB4 in Leydig cells and diminution the sequel of steroidogenic phenomena.

On the other hand the main second messenger of testosterone production calcium influence and act as sort acting regulation of steroidogenic endpoint (22).

In fact cases that proportion of gonadotrophs from the steroidogenesis pathway had oscillatory $\mathrm{Ca}^{+2}$ responses to $\mathrm{GnRH}$ was assess the importance of testosterone metabolism mediated dihydrotestosterone (21), and Lin (2008) documented this phenomenal as GnRH directly stimulated murine Leydig cell steroidogenesis by activating $3 \beta-\mathrm{HSD}$ enzyme expression (14).

Ludwig (1991) validate the cells form LTB4 in response to $\mathrm{GnRH}$ and run strong support for the hypothesis that LTs act as second messengers in the GnRH signaling pathway (13).

However, in humans, expression of GnRH-I in Sertoli cells and GnRH-R in Leydig cells has been shown [3], indicating that GnRH may function in testicular steroidogenesis (14).

Sullivan and Cooke (1985) were attributed the increase of LTB4 to produce in Leydig cells and can be stimulated by high Calcium levels, but that it is probably not required for the control of steroidogenesis (15). This finding was approved by Wang and Xiao (1993) (22) the captopril down regulated and uptake of the Calcium concentration. That gave an attribution decrease of testosterone may be due to direct reduction of Calcium levels as well as indirect of lessening of LTB4 Figure (5) in Leydig cell treated with captopril besides opposite result directed through activated by GnRH and Both GnRH-LH. Whereas the speculation of above probability the LTB4 not contribution in steroidogenic activity was uncompleted given fullness riposte. Because the reduction of Calcium-LTB4 pathway by captopril not complete upset of steroidogenic testosterone levels (figure 8).

The GnRH administration recovers the testosterone level coincided control culture media at first 6 hour of incubation period; whereas, the curves were significantly diverge until end of incubation figure (7). That approved the Leydig cell culture presumably had dual term of regulation first short term and later long term according of incubation period and homeostasis regulation. The captopril block $\mathrm{Ca}^{+2}$ LTB4 short term period (34) and non-complete LTB4 blocked may be evoked the partially steroidogenic indirectly by deletion activity of MEK1/2 in Leydig cells results in Leydig cells hypoplasia and hypofunction (23). Or presumably through a novel positive local loop involving FASN/p-ERK1/2/5-LOX/LTB4/FASN contributes to the sustaining growth of cells (24).

The study was concluded the LTB4 had a role in steroidogenic activity of Leydig cell under GnRH stimulation with notable contribution other indirect pathway to motivate testosterone secretion.

\section{Acknowledgment}

I acknowledge the training and ethical support to Prof. Dr. Wael Khamas, (College of Veterinary Medicine; Western 
University, California, Pomona) for the Leydig cells isolation protocol and his valuable comments with advice, and Andrea Wournell; (Molecular Biology, Lab; Western University, California, Pomona) for training on testicular cell isolation.

\section{References}

[1] Zhang L. and Cui S., "Effects of daidzein on testosterone synthesis and secretion in cultured mouse leydig cells," AsianAustralasian Journal of Animal Sciences, vol. 22, no. 5, pp. 618-625, 2009.

[2] Shuying Huo, Xiuhui Zhong, Xianjun $\mathrm{Wu}$, and Yurong Li, "Effects of Norepinephrine and Acetylcholine on the Development of Cultured Leydig Cells in Mice," Journal of Biomedicine and Biotechnology, vol. 2012, Article ID 503093, 8 pages, 2012. doi:10.1155/2012/503093

[3] Zhao, M., J. Rohozinski, M. Sharma, J. Ju, R.E. Braun, C.E. Bishop, and M.L. Meistrich. 2007. Utp14b: a unique retrogene within a gene that has acquired multiple promoters and a specific function in spermatogenesis. Dev. Biol. 304:848-859.

[4] Anway, M.D., J. Folmer, W.W. Wright, and B.R. Zirkin. 2003. Isolation of sertoli cells from adult rat testes: an approach to ex vivo studies of Sertoli cell function. Biol. Reprod. 68:996-1002.

[5] O'Shaughnessy, P.J., I.D. Morris, I. Huhtaniemi, P.J. Baker, and M.H. Abel. 2009. Role of androgen and gonadotrophins in the development and function of the Sertoli cells and Leydig cells: data from mutant and genetically modified mice. Mol. Cell. Endocrinol. 306:2-8.

[6] Cheng, C.Y. and D.D. Mruk. 2010. A local autocrine axis in the testes that regulates spermatogenesis. Nat. Rev. Endocrinol. 6:380-395.

[7] Luteinizing Hormone Receptors and Testosterone Synthesis in Two Distinct Populations of Ley dig Cells ANITA H. PAYNE, JAMES R. DOWNING, and KAR-LIT WONG Endocrinology 1980 106:5, 1424-1429

[8] Guoxin Wang, Dawei Chen, Haoshu Luo, Jiali Liu, Xiaowen Ji, Jingjing Fan, Sheng Cui 2010., "Low-dose ethanol suppresses17 $\beta$-estradiol activity in GH4C1 pituitary tumor cells," Cell Biology and Toxicology, Vol. 26, no. 3, pp. 265277, 2010.

[9] Huamin J, Ci Z, Hui S, Yong L, Huijun Q, Bingyan Z (2002). Determination of pretransplant viability of Leydig cells by MTT colorimetric assay. Transplant Proc. 34(8):3419-21

[10] Wang N. G, Sundaram K, Pavlou S, Rivier J, Vale W, Bardin CW. (1983) Mice are insensitive to the antitesticular effects of luteinizing hormone-releasing hormone agonists. Endocrinology; 112: 331-5.

[11] K Shindo, J R Baker, D A Munafo, and T D Bigby (1994) Captopril inhibits neutrophil synthesis of leukotriene B4 in vitro and in vivo. J Immunol ; 153:5750-9

[12] Chen Barbara B, Helen Chen, Malecha James W, Miyashiro Julie M, Penning Thomas D, Russell Mark A. (1998) LTB4 hydrolase inhibitors; invention WO 1998040364 A1

[13] Ludwig K., Andrzej F., Andreas J., Maria S. Przylipiak, and Benno R. (1991) Production of leukotrienes in gonadotropinreleasing hormone-stimulated pituitary cells: Potential role in luteinizing hormone release Proc. Nati. Acad. Sci. USA Vol. 88, pp. 8801-8805,

[14] Lin, Yung-Ming Lin, Ming-Yie Liu, Song-Ling Poon, SewFen Leu, Bu-Miin Huang (2008) Gonadotrophin-releasing hormone-I and -II stimulate steroidogenesis in prepubertal murine Leydig cells in vitro. Asian J Androl; 10 (6): 929-936

[15] Sullivan, M. and Brian A. (1985) Control and production of leukotriene B4 in rat tumour and testicular Leydig cells Biochem. J. 230, 821-824

[16] PJ Baker, H Johnston, M Abel, HM Charlton and PJ O'Shaughnessy (2003) Differentiation of adult-type Leydig cells occurs in gonadotrophin-deficient mice Reproductive Biology and Endocrinology, 1:4

[17] Shapiro, R. and Riordan, J.F. (1984) Biochemistry. 23: 52255233.

[18] Antonino M., Anna G., Massimo Z., Luna Q., Ennio M., Oretta M., Domenico A., and Massimo B. (1999) the American Physiological Society R1261-R1267

[19] Tu Un (1984) Mechanism of Action of Gonadotropinreleasing Hormone-stimulated Leydig Cell Steroidogenesis, I. The Stimulatory Effect is Calcium Dependent and Not Mediated by Cyclic Nucleotides J. Androl., 5:193-200.

[20] Bing Yao, Hai-Yan Liu, Yu-Chun Gu, Shan-Shan Shi, XiaoQian Tao, Xiao-Jun Li, Yi-Feng Ge, Ying-Xia Cui and GuoBin Yang (2011) Gonadotropin-releasing hormone positively regulates steroidogenesis via extracellular signal-regulated kinase in rat Leydig cells. Asian Journal of Andrology, 13, $438-445$

[21] Tobin V. A. and Canny B. J. (1998) The Regulation of Gonadotropin-Releasing Hormone- Induced Calcium Signals in Male Rat Gonadotrophs by Testosterone Is Mediated by Dihydrotestosterone. Endocrinology Vol. 139, No. 3 10381045

[22] WANG Ju-Feng, XIAO W en-Bin (1993) Effects of lisinopril and captopril on calcium in rat heart. Acta Pharma ologica Sinica ; 14(3) : 197—200

[23] Soichi Yamashita, Ping Tai, Jean Charron, CheMyong Ko, and Mario Ascoli (2011) The Leydig Cell MEK/ERK Pathway Is Critical for Maintaining a Functional Population of Adult Leydig Cells and for Fertility, Mol Endocrinol. Jul 2011; 25(7): 1211-1222

[24] Nan Hu, Yu Li, Yu Zhao, Qi Wang, Jia-cong You, Xiao-dong Zhang and Li-hong Ye (2011) A novel positive feedback loop involving FASN/p-ERK1/2/5-LOX/LTB4/FASN sustains high growth of breast cancer cells, Acta Pharmacologica Sinica (2011) 32: 921-929; 40.

[25] Shindo K, Baker JR, Munafo DA, Bigby TD. (1994) Captopril inhibits neutrophil synthesis of leukotriene B4 in vitro and in vivo. J. Immunol. 15; 153(12):5750-9.

[26] Schilsky R. L., Lewis B. J., Sherins R. J., and Young R. C., "Gonadal dysfunction in patients receiving chemotherapy for cancer," Annals of Internal Medicine, vol. 93, no. 1, pp. 109114, 1980.

[27] Molcho J, Zakut H, Naor Z. (1984) Stimulation of prostaglandin $\mathrm{E}$ and testosterone production in rat interstitial cells by a gonadotropin-releasing hormone agonist. Endocrinology; 114: 2382-7. 
[28] Browning JY, D'Agata R, Steinberger A, Grotjan Jr. HE, Steinberger E. (1983) Biphasic effect of gonadotropinreleasing hormone and its agonist analog (HOE766) on in vitro testosterone production by purified rat Leydig cells. Endocrinology; 113: 985-91.

[29] Kerr JB, Sharpe RW. (1986) Effects and interactions of LH and LHRH agonists on testicular morphology and function in hypophysectomized rats; J Reprod Fertil; 76: 175-92.

[30] Habert R. (1992) Effect of decapitation and chronic in-vivo treatment with a gonadotrophin-releasing hormone agonist on testicular steroidogenesis in the rat fetus. J Endocrinol, 133: 245- 51.

[31] Romanelli F, Valenca M, Conte D, Isidori A, and Negro-Vilar A. (1995) Arachidonic acid and its metabolites effects on testosterone production by rat Leydig cells. J Endocrinol. Invest; 18(3):186-93.

[32] Mi Kyung Park, Youngran Park, Jaegal Shim, Hye Ja Lee, Sanghee Kim, Chang Hoon Lee (2012) Novel involvement of leukotriene B4 receptor 2 through ERK activation by PP2A down-regulation in leukotriene B4-induced keratin phosphorylation and reorganization of pancreatic cancer cells Biochimica et Biophysica Acta 1823 (2012) 2120-2129.

[33] Meztli Arguello, Suzanne Paz, Eduardo Hernandez, Catherine Corriveau-Bourque, Lama M. Fawaz, John Hiscott2, and Rongtuan Lin (2006) Leukotriene A4 Hydrolase Expression in PEL Cells Is Regulated at the Transcriptional Level and Leads to Increased Leukotriene B4 Production J Immunol 2006; 176:7051-7061.

[34] Wang Ju-Feng, Xiao W en-Bin (1993) Effects of lisinopril and captopril on calcium in rat heart, Acta Pharmacologica Sinica 14 (3)

[35] Verjans, H.L., Cooke, B.A., de Jong, F.H., de Jong, CM.M. \& van der Molen, H.J. (1973) Evaluation of a radioimmunoassay for testosterone estimation. Steroid Biochem. 4, 665-676.

[36] Salmon, J.A., Simmons, P.M. and Moncada, S. (1983). The effects of BW $755 \mathrm{C}$ and other anti-inflammatory drugs on eicosanoid concentrations and leukocyte accumulation in experimentally induced acute inflammation. J. Pharm. Pharmacol., 35, 808-813. 